\title{
EFFICIENCY OF THREE CHEMICAL AND TWO BIOLOGICAL INSECTICIDES ON TUTA ABSOLUTA LARVAE IN THE FIELD OF TOMATO AT EL BEHEIRA GOVERNORATE
}

\author{
Pansea A. Azzam ${ }^{(1)}$, E. F. El-Khayat ${ }^{(2)}$, M.F. Hegab ${ }^{(1)}$, \\ Tahany R. Abd- El-Zaher ${ }^{(2)}$ and A. B. Badran ${ }^{(1)}$ \\ (1) Plant Protection Research Institute, (A.R.C.), Dokki, Giza, Egypt \\ (2) Plant Protection Dept. Fac. Agric. Moshtohor, Benha University, Egypt
}

Received : May 23, 2017

Accepted: May 27, 2017

ABSTRACT: Chemical insecticides: Coragen (chlorantraniliprole), Voliam- Flexi (thimethoxam 20\% + chlorantraniliprole) and Proclaim (emamectin benzoate), and the two bioinsecticides Vertimec (abamectin) and Dipel $2 X$ (Bacillus thuringiensis), were evaluated in the present study in Bader district during tomato spring plantation 2016, for their efficacy in the control of Tuta absoluta (Meyrick) (Lepidoptera: Gelechiidae) infesting tomato plants. The grand mean effect of the two tested applications showed that Vertimec. was the superior in the control of the insect pest causing $72.7 \%$ reduction in larval stages, followed by $69.7 \%$ for both of Voliam- Flexi and Coragen, while Dipel $2 X$ recorded (65.3\%) and Proclaim (64.16\%).

Key words: Tomato, Avermectin, Abamectin, Neonicotinoid, Bacillus thuringiensis, Biocontrol.

\section{INTRODUCTION}

Tomato, Lycopersicon esculentum (Mill) belonging to family Solanaceae which is important and remunerative vegetable crop grown around the world for fresh market and processing (Salunkh et al., 1987). Annual production accounts estimated by about 107 million metric tons a fresh market tomato representing $72 \%$ of the total vegetables production (FAO, 2002).

The tomato leaf miner, Tuta absoluta (Meyrick) (Lepidoptera: Gelchiidae) is a serious pest of both outdoor and greenhouses tomatoes (CFIA, 2010). Tuta absoluta larvae feed on the leaves of several species of solanaceous plants. This insect pest was recorded on many solanaceous species, including pepper, eggplant and potato plants.

The insect deposits eggs usually on the leaves, stems and lesser extend on fruits. After hatching young larvae penetrate into tomato fruits, leaves on which they feed and develop creating mines and galleries on leaves, larvae feed only on mesophyll leaving the epidermis intact (OEPP, 2005). Tomato plants can be attacked at any developmental stage, from seedling to mature stage.

Up to $100 \%$ losses have been reported in tomato crops and even where chemicals control are implemented, losses can still exceed 5\% (Korycinska and Moran, 2009).

The present experimental trail was implemented to evaluate the effect of three chemical and two bioinsecticides on the larval instars of that serious pest on tomato plants along two successive sprays.

\section{MATERIAL AND METHODS}

The present study was conducted at Badr district, El Beheira Governorate, to evaluate the efficacy of three insecticides, and two bio insecticides in the following table.

To evaluate their efficiency in controlling Tuta absoluta larvae, one feddan was planted by tomato seedling, variety (Heinz). The normal agricultural practices were carried out. The field was divided into 18 plots (6 treatments* 3 replicates). A total plots were considered for each tested insecticides. Two sprays were applied, 10 days between them, the first was after 30 
Pansea A. Azzam, et al.,

days from transplanting, and the second application was sprayed after 10 days from spraying the first application. Sampling started before the first application directly, samples of 15 leaflets/ replicate were picked up randomly from the medium vertical plants level after 3,5 and 10 days from spraying (45 leaflet/ treatment) were put in a paper bags and transferred to the laboratory for examining and counting the alive larvae. The reduction percentages of Tuta absoluta larvae was determined according to the equation adopted by Handerson and Tilton (1955).

Obtained data were submitted to analysis of variance (ANOVA) and recording the mean number of alive larvae at probability level 0.05 .

\section{RESULT AND DISCUSSION}

The obtained results in Tables (1), (2) and (3) indicated that the tested insecticides showed almost close effects in reducing the larvae of Tuta absoluta insect pest infesting tomato plants under field conditions.

After the first spray with tested pesticides, the initial effect after 3 days from spraying the tested treatments recorded reduction $\%$ as $67 \%, 69 \%, 58 \%, 61$ and $95 \%$ in the larval population with VoliamFlexi, Coragen, Proclaim, Dipel 2X and Vertimec, respectively. In the $5^{\text {th }}$ day after spray the reduction percentages was highly increased recording $84 \%, 83 \%, 80 \%, 83 \%$ and $79 \%$. Ten days after pesticides application, the reduction percentages was continued in increase recording $90 \%$, $89 \%, 82 \%, 75 \%$ and $82 \%$ for the above mentioned insecticides, respectively.

The grand mean reduction percentages in Tuta absoluta larvae by the first spray was $80.33 \%$ with Voliam- Flexi and Coragen followed by $73.33 \%, 73 \%$ and $72.33 \%$ for Proclaim, Dipel $2 \mathrm{X}$ and Vertimec, respectively.

Statistical analysis proved the significant variation between the mean numbers of larvae / sample after 3, 5 and 10 days after spraying and the grand mean with $F$. values and L.S.D. presented in Table (1).

Almost similar results in reducing the tomato leaf miner $T$. absoluta larval infestation were obtained by the second spray application after ten days from the first spray Table (2) where the reduction percentages in larvae were $49 \%, 46 \%, 44 \%$, $39 \%$ and $57 \%$ after 3 days from spraying, $56 \%, 60 \%, 58 \%, 54 \%$ and $75 \%$ after 5 days from spraying and $73 \%, 71 \%, 63 \%, 80 \%$ and $81 \%$ population reduction after 10 days from spraying for Voliam- Flexi, Coragen, Proclaim, Dipel $2 X$ and Vertimec, respectively.

\section{Table of tested pesticides}

\begin{tabular}{|l|l|c|l|c|}
\hline \multicolumn{1}{|c|}{$\begin{array}{c}\text { Trade name } \\
\text { formulation }\end{array}$} & \multicolumn{1}{|c|}{$\begin{array}{c}\text { Active } \\
\text { Ingredient }\end{array}$} & $\begin{array}{c}\text { Recomm- } \\
\text { ended } \\
\text { dose/100 L } \\
\text { water }\end{array}$ & Class/group & $\begin{array}{c}\text { Pre harvest } \\
\text { interval } \\
\text { PHI(Day) }\end{array}$ \\
\hline $\begin{array}{l}\text { Voliam } \\
\text { Flexi40\%WG }\end{array}$ & $\begin{array}{l}\text { Thiamethoxam 20\%+ } \\
\text { Chiorantraniliprole }\end{array}$ & $20 \mathrm{~g}$ & $\begin{array}{l}\text { Neonicotinoid } \\
\text { + Diamide }\end{array}$ & 10 \\
\hline Coragen20\% SC & Chloantraniliprole & $15 \mathrm{~cm}$ & Diamide & 7 \\
\hline Proclaim5\% SG & Emamectin benzoate & $30 \mathrm{~g}$ & Avermectin & 5 \\
\hline Vertimec1.8\% EC & Abamectin & $40 \mathrm{~cm}$ & Abamectin & 14 \\
\hline Dipel 2X 6.4\% DF & Bacillus thuringiensis & $100 \mathrm{~g}$ & Bio & $\mathrm{N} / \mathrm{A}$ \\
\hline control & Water & & & \\
\hline
\end{tabular}

$\mathrm{SC}=$ Suspension concentrate.

$W G=$ Wettable dispersible granules .

$S G=$ Soluble granules.
$\mathrm{EC}=$ Emulsifiable concentrate

$\mathrm{N} / \mathrm{A}=$ Not applicable

$\mathrm{DF}=$ Dry flowable 
Table (1): Effect of five treatments on Tuta absoluta larvae infesting tomato plants in EI Beheira Governorate (first spray) during spring plantation of 2016 season

\begin{tabular}{|c|c|c|c|c|c|c|c|c|c|c|}
\hline \multirow{3}{*}{$\begin{array}{c}\text { Treatment } \\
\text { Voliam- Flexi }\end{array}$} & \multirow{3}{*}{$\begin{array}{c}\text { Rate/ } \\
100 \mathrm{~L} . \\
\text { water } \\
20 \mathrm{~g}\end{array}$} & \multicolumn{7}{|c|}{ Mean number of larvae/ 15 leaflets and reduction $\%$} & \multirow{3}{*}{$\begin{array}{c}\begin{array}{l}\text { Grand } \\
\text { mean }\end{array} \\
12.2 \text { bc }\end{array}$} & \multirow{3}{*}{$\begin{array}{l}\text { Grand } \\
\text { mean } \\
\text { Red\% }\end{array}$} \\
\hline & & \multirow{2}{*}{$\begin{array}{c}\begin{array}{c}\text { before } \\
\text { spray }\end{array} \\
25\end{array}$} & \multicolumn{2}{|c|}{ after 3 days } & \multicolumn{2}{|c|}{ after 5 days } & \multicolumn{2}{|c|}{ after 10 days } & & \\
\hline & & & $11.0 \mathrm{ab}$ & $67 \%$ & $7.0 \mathrm{~b}$ & $84 \%$ & $5.7 d$ & $90 \%$ & & \\
\hline Coragen & $15 \mathrm{~cm}$ & 20 & $8.3 \mathrm{ab}$ & $69 \%$ & $6.0 \mathrm{~b}$ & $83 \%$ & $4.3 \mathrm{~d}$ & $89 \%$ & $9.7 \mathrm{c}$ & $80.3 \%$ \\
\hline Proclaim & $30 \mathrm{~g}$ & 20.7 & $11.7 \mathrm{ab}$ & $58 \%$ & $7.3 \mathrm{~b}$ & $80 \%$ & $9.0 \mathrm{c}$ & $82 \%$ & $12.2 \mathrm{ab}$ & $73.3 \%$ \\
\hline Dipel 2X & $100 \mathrm{~g}$ & 22.3 & $11.7 \mathrm{ab}$ & $61 \%$ & $6.7 \mathrm{~b}$ & $83 \%$ & $14.7 \mathrm{a}$ & $75 \%$ & $13.8 \mathrm{ab}$ & $73.0 \%$ \\
\hline Vertimec & $40 \mathrm{~cm}$ & 25.3 & $14.0 \mathrm{a}$ & $59 \%$ & $10.3 a$ & $79 \%$ & $11 \mathrm{~b}$ & $82 \%$ & $15.2 \mathrm{a}$ & $72.3 \%$ \\
\hline Control & - & 28.3 & 38.3 & - & 49.3 & - & 71.0 & - & 52.9 & - \\
\hline F. value & - & - & \multicolumn{2}{|c|}{2.06} & \multicolumn{2}{|c|}{3.83} & \multicolumn{2}{|c|}{86.22} & 4.6 & - \\
\hline L.S.D.5\% & - & - & \multicolumn{2}{|c|}{4.456} & \multicolumn{2}{|c|}{2.69} & \multicolumn{2}{|c|}{1.409} & 2.7 & - \\
\hline
\end{tabular}

Means in each column followed by the same letter are not significantly different at $5 \%$ level.

Table (2): Effect of five treatments on Tuta absoluta larvae infesting tomato plants in EI Beheira Governorate (second spray) during spring plantation of 2016 season.

\begin{tabular}{|c|c|c|c|c|c|c|c|c|c|c|}
\hline \multirow{3}{*}{$\begin{array}{l}\text { Treatment } \\
\text { Voliam- Flexi }\end{array}$} & \multirow{3}{*}{$\begin{array}{l}\text { Rate/ } \\
100 \mathrm{~L} . \\
\text { water } \\
20 \mathrm{~g}\end{array}$} & \multicolumn{7}{|c|}{ Mean number of larvae/ 15 leaflets and \% reduction } & \multirow{3}{*}{$\begin{array}{c}\begin{array}{c}\text { Grand } \\
\text { mean }\end{array} \\
3.3 \mathrm{c}\end{array}$} & \multirow{3}{*}{$\begin{array}{l}\text { Grand } \\
\text { mean } \\
\text { Red\% }\end{array}$} \\
\hline & & \multirow{2}{*}{$\begin{array}{c}\begin{array}{r}\text { before } \\
\text { spray }\end{array} \\
5.7\end{array}$} & \multicolumn{2}{|c|}{ after 3 days } & \multicolumn{2}{|c|}{ after 5 days } & \multicolumn{2}{|c|}{ after 10 days } & & \\
\hline & & & $3.0 \mathrm{c}$ & $49 \%$ & $2.7 \mathrm{~b}$ & $56 \%$ & $1.7 \mathrm{ab}$ & $73 \%$ & & \\
\hline Coragen & $15 \mathrm{~cm}$ & 4.3 & $3.0 \mathrm{c}$ & $46 \%$ & $2.3 \mathrm{~b}$ & $60 \%$ & $1.7 \mathrm{ab}$ & $71 \%$ & $2.8 \mathrm{c}$ & $59 \%$ \\
\hline Proclaim & $30 \mathrm{~g}$ & 9.0 & $5.3 \mathrm{~b}$ & $44 \%$ & $4.0 \mathrm{~b}$ & $58 \%$ & $3.7 \mathrm{a}$ & $63 \%$ & $5.5 \mathrm{~b}$ & $55 \%$ \\
\hline Dipel 2X & $100 \mathrm{~g}$ & 14.7 & $8.7 \mathrm{a}$ & $39 \%$ & $6.7 \mathrm{a}$ & $54 \%$ & $3.0 \mathrm{ab}$ & $80 \%$ & $8.3 a$ & $57.6 \%$ \\
\hline Vertimec & $40 \mathrm{~cm}$ & 11 & $5 b$ & $57 \%$ & $3 \mathrm{~b}$ & $75 \%$ & $2.0 \mathrm{ab}$ & $81 \%$ & $5.3 \mathrm{~b}$ & $71 \%$ \\
\hline Control & - & 71 & 74.6 & - & 76.3 & - & 79 & - & 76.6 & - \\
\hline F. value & - & - & \multicolumn{2}{|c|}{22.05} & \multicolumn{2}{|c|}{9.23} & \multicolumn{2}{|c|}{2.4} & 22.7 & - \\
\hline L.S.D.5\% & - & - & \multicolumn{2}{|c|}{1.557} & \multicolumn{2}{|c|}{1.819} & \multicolumn{2}{|c|}{1.819} & 1.3 & - \\
\hline
\end{tabular}

Means in each column followed by the same letter are not significantly different at $5 \%$ level.

It is worth to say that the effect of the tested treatments was less comparing with the results of the first spray that may due to the quick adaptation of this insect, which is a famous character for it, in addition to the very smallest population of the pest before the second spray showed that the control of this pest is difficult because manifestation of resistance to great part of applied insecticides.

Statistical analysis of the obtained data presented in Table (2) proved the significance of the differences between the effects of the tested treatments, $F$ values and L.S.D. at 0.05 level.

The grand mean effect of the two tested applications in Table (3) showed the same observation and results in Table (1) and (2) indicating that Vertimec in the rate of $40 \mathrm{~cm}$. was the superior for controlling the insect pest causing $72.66 \%$ reduction followed by $69.66 \%$ for Voliam- Flexi and Coragen, Dipel $2 \mathrm{X}(65.3 \%)$ and Proclaim (64.16\%). 
Pansea A. Azzam, et al.,

Table (3): The grand mean number and reduction \% by the two sprays of 5 insecticdes on Tuta absoluta larvae infesting tomato plants at El Beheira Governorate

\begin{tabular}{|l|c|c|c|}
\hline \multicolumn{1}{|c|}{ Treatment } & Rate / 100 L. water & $\begin{array}{c}\text { Grand mean of larvae/ } \\
\text { 15 leaflets }\end{array}$ & Grand reduction \% \\
\hline Voliam- Flexi & $20 \mathrm{~g}$ & $7.7 \mathrm{~cd}$ & $69.7 \%$ \\
\hline Coragen & $15 \mathrm{~cm}$ & $6.3 \mathrm{~d}$ & $69.7 \%$ \\
\hline Proclaim & $30 \mathrm{~g}$ & $8.8 \mathrm{cb}$ & $64.2 \%$ \\
\hline Dipel $2 X$ & $100 \mathrm{~g}$ & $11.04 \mathrm{a}$ & $65.3 \%$ \\
\hline Vertimec & $40 \mathrm{~cm}$ & $10.2 \mathrm{ab}$ & $72.7 \%$ \\
\hline F. value & - & 8.16 & - \\
\hline L.S.D. 5\% & - & 1.9 & - \\
\hline
\end{tabular}

Means in each column followed by the same letter are not significantly different at $5 \%$ level.

Similar results have been reached by Astor and Scals (2009), in Spain reported the efficacy of [chlorantraniliprole] with another pesticides in integrated control programmers for the tomato insect pest, Gonzalez-Cabrera et al. (2009) and (2011), in Spain found that B.t compounds could be a good agent in controlling $T$. absoluta, Linden and Staaij (2011), showed that abamectin (vertimec) and emamectin benzoate (proclaim) were effective against T. absoluta, Bassi et al. (2012), in Brazil referred to Chlorantraniliprole is a novel diamide insecticide with outstanding performance on Tuta absoluta, Biondi et al. (2012), showed that Integrated Pest Management (IPM) programs may include pesticide applications for controlling $T$. absoluta The tested chemicals were abamectin, Bacillus thuringiensis and emamectin benzoate, Valchev et al. (2013), found that the control of this pest is difficult because of the latent way of life of the larvae in the mines, high reproductive potential, polyvoltine development and manifestation of resistance to great part of applied insecticides. For control $T$. absoluta it is still that the application of chemical insecticides is very good with biological activity towards the larvae was Coragen 20 SC causing $79.18 \%$ reduction 14 th day after treatment. Birgucu et al. (2014), in Turkey found that insecticides used against Tuta absoluta Chlorantraniliprole + abamectin, emamectin benzoate, all individuals treated larvae were died at the 7 DAA. Ingegno et al. (2014), evaluated Bacillus thuringiensis and emamectin benzoate against $T$. absoluta, Soliman et al. (2014), in Egypt reported that the percent reduction in infestation was 79.73 using Emamectin benzoate, Ayalew (2015), in Ethiopia showed that plots treated with diamide insecticides (chlorantraniliprole) fruit infestation was significantly lower with $2-6 \%$ fruit damage, Bratu et al. (2015), showed that emamectin-benzoate used once at a rate of $14.25 \mathrm{~g}$ a.i./ha had high efficacy (99.0\%) and finally Osman (2015), in Egypt recorded that Proclaim and Coragen achieved highest accumulated mortalities in Tuta absoluta larvae (100\%) 5 days post treatment.

\section{REFERENCES}

Astor, E. and Scals, D. de (2009). The control of Tuta absoluta with insecticides compatible with integrated pest management programmes and the prevention of resistance. [Spanish] Agricola Vergel: Fruticultura, Horticultura, Floricultura, Citricultura, Vid, Arroz; . 28(333): 492-495.

Ayalew, G. (2015). Efficacy of selected insecticides against the South American tomato moth, Tuta absoluta Meyrick (Lepidoptera: Gelechiidae) on tomato in the Central Rift Valley of Ethiopia. African Entomology; 23(2):410-417.

Bassi, A., Rison, J. L., E. Roditakis and L. Sannino (2012). Chlorantraniliprole 
(RynaxypyrReg., $\quad$ CoragenReg., AltacorReg.) key features for sustainable control of Tutaabsoluta. IOBC/WPRS Bulletin; 80:193-198.

Biondi, A., N. Desneux, G. Siscaro, G. T. Garzia, E. Amiens-Desneux and L. Zappala (2012). Side effects of bioinsecticides used to control Tuta absoluta. IOBC/WPRS Bulletin; 80:211216

Birgucu, A. K., A. Bayndr, Y. Celikpence and I. Karaca (2014). Growth inhibitory effects of bio- and synthetic insecticides on Tuta absoluta (Meyrick, 1917) (Lepidoptera: Gelechiidae). Turkiye Entomoloji Dergisi; 38(4):389-400.

Bratu, E., A. M. Petcuci and G. Sovarel (2015). Efficacy of the product Spinosad an insecticide used in the control of tomato leafminer (Tutaabsoluta Meyrick, 1917). Bulletin of University of Agricultural Sciences and Veterinary Medicine Cluj-Napoca. Horticulture; 72(1):209-210.

CFIA, (2010). Tomato leafminer- Tuta absoluta. Pest Fact Sheet. .http://www.inspection.gc.ca/english/plav eg/pestrava/tutabs/tech/tutabse. shtml.

FAO. (2002). Production year book 200. VI. 54. FAO. Italy.

Gonzalez-Cabrera, J., O. Molla and A. Urbaneja (2009). Biological control of Tuta absoluta (Meyrick) (Lepidoptera: Gelechiidae) with Bacillus thuringiensis (Berliner). [Spanish]Agricola Vergel: Fruticultura, Horticultura, Floricultura, Citricultura, Vid, Arroz; 28(333):476-480.

Gonzalez-Cabrera, J., O. Molla, H. Monton and A. Urbaneja (2011). Efficacy of Bacillus thuringiensis (Berliner) in controlling the tomato borer, Tuta absoluta (Meyrick) (Lepidoptera: Gelechiidae). Bio Control; 56(1):71-80.

Henderson, C. F. and E. W. Tilton (1955). Tested with acaricides against the brown wheat mite (J. Econ. Ent; 48:157-161).

Ingegno, B. L., S. Frati and L. Tavella (2014). Control strategies against Tuta absoluta in tomato greenhouses. IOBC/WPRS Bulletin; 102:103-110.

Korycinska, A. and H. Moran (2009). South American tomato moth Tuta absoluta. The Food and Environmental Research Agency

(Fera)www.defra.gov.uk/fera/plants/plant Health.

Linden, A. van der and Staaij, M. van der (2011). Effectiveness of pesticides and potential for biological control of the tomato leaf miner Tuta absoluta (Meyrick) (Lepidoptera: Gelechiidae) in Europe. IOBC/WPRS Bulletin; 68:97100.

OEPP/ EPPO. (2005). European and Mediterranean Plant Protection Organization 2005. Tuta absoluta. Bulletin OEPP/ EPPO Bulletin. 35:434435.

Osman, M. A. M. (2015). Evaluation of two protective strategies for controlling the tomato leaf miner Tuta absoluta (Meyrick) (Lepidoptera: Gelechiidae) in Egypt. Egyptian Journal of Biological Pest Control; 25(1):113-120.

Salunkhe, D.K., B.B. Desai and N.R. Bhat (1987). Vegetable and flower seed production. 1 st. Edn. Agricole pub. Acad. New Delhi, India, pp: 135.

Soliman, M. M. M., A. S. H. Abdel-Moniem and M. A. Abdel-Raheem (2014). Impact of some insecticides and their mixtures on the population of tomato borers, Tuta absoluta (Meyrick) (Lepidoptera: Gelechiidae) and Helicoverpa armigera (Hubner) (Lepidoptera: Noctuidae) in tomato crop at Upper Egypt. Archives of Phytopathology and Plant Protection; 47(14):1764-1776.

Valchev, N., V. Yankova and D. Markova (2013). Biological activity of plant protection products against Tuta absoluta (Meyrick) in tomato grown in greenhouses. Agricultural Science and Technology; 5(3):318-321. 
كفاعة ثلاثة مبيدات حثرية كيميائية و اثنان من المبيدات الحثرية البيولوجية ضد يرقات صانعة انفاق الطماطم بمحافظة البحيرة

بانسيه عبد السلام عزام(1) ، عزت فرج الخياط(2) ، محمد فهمى حجاب(1) ،

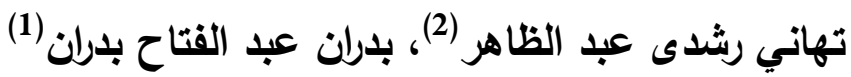

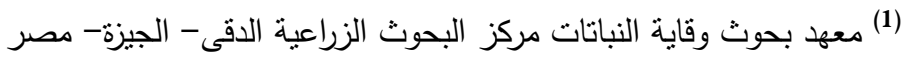
(2) كلية الزراعة بمشتهر - جامعة بنها الملخص العربى

تعتبر حشرة صانعة أنفاق الطماطم أوحافرة الطماطم من أهم الآفات المدمرة لمحصول الطماطم بل تعتبر في الآونة

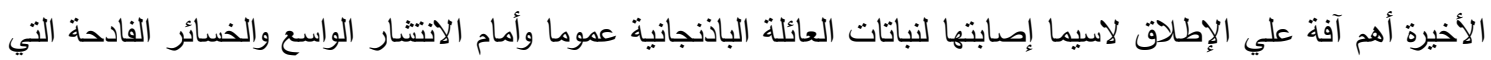

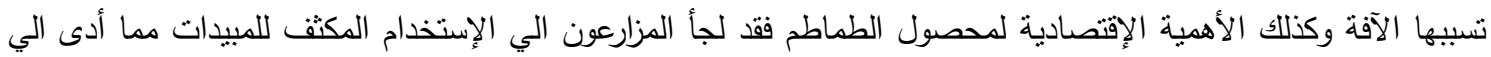
ظهور صفة الدقاومة وبالتالى ضعف نتائج الدكافحة.

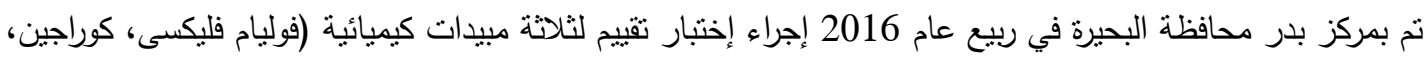

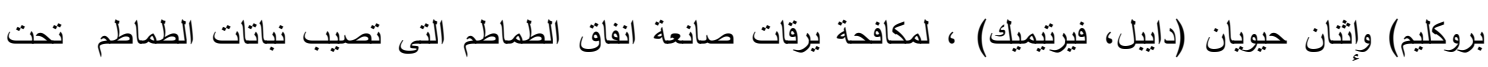

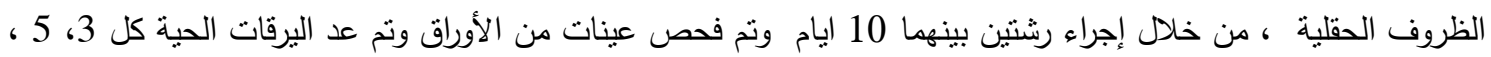

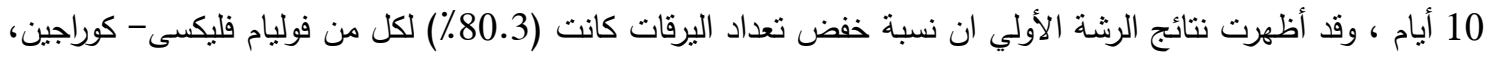

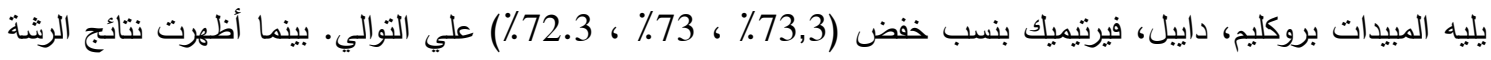

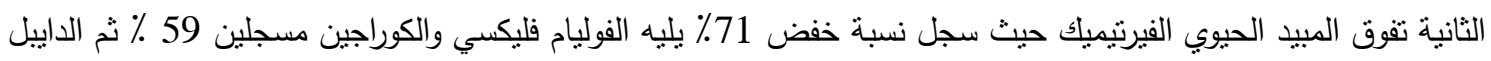

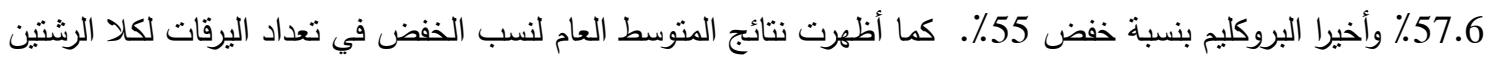
حيث جاء الفيرتيمك في المركز الأول بنسبة 72,7٪ يلية الفوليام فليكسي والكوراجين بنسبة خفض 69.7٪ ثم الداييل بنسبة 65.3٪ وجاء البروكليم فى المركزالأخير بنسبة خفض264.2٪. 